\title{
Construction of Total Information Portal Service for Korea Urban Regeneration
}

\author{
Dong-Suk Yang ${ }^{1}$ and Yeong-Hwa $\mathrm{Yu}^{2}$ \\ (Received February 13, 2012 / Revised July 26, 2012 / Accepted July 27, 2012)
}

\begin{abstract}
In this study, the total information portal service for urban regeneration was constructed to supply comprehensive information for Korean urban regeneration. The portal service is largely divided into an information analysis service for urban regeneration and an information disclosure service. For total information portal service, the information analysis service constructed a system for making district level decline diagnosis and city and county level potential analysis. Moreover, it can construct and control analyzed information specified at the district level. The information disclosure service consists of functions capable of recycling information, interworking the analysis service and facilitating expert participation. It also supplies data of total information DB in reprocessable format. For revitalization of communities, the information analysis service is constructed to lead experts on urban regeneration to share their opinions.
\end{abstract}

Key words: Urban Regeneration, Total Information Portal, Decline Diagnosis, Urban Potential, Urban Regeneration Information DB

\section{Introduction}

\subsection{Research Background and Purpose}

In view of improvement of urban competitiveness, a more rational decision-making system is required to promote urban regeneration projects. In order to construct an urban decline diagnosis system in consideration of diversity and complexity, a total diagnosis system with physical, social, economic and cultural elements should be constructed. Moreover, an increase in demand on various convergence applications of information leads to the necessity to reinforce the connection with the existing information supply systems for urban regeneration and their utilization. The precedent studies show that urban decline diagnosis systems and indicator databases were constructed to monitor the contents and degree of urban decline at the city, county and district levels. This study aims to construct a total information portal service for urban regeneration to implement a total information service for Korean urban regeneration, in terms of district level decline and urban potential diagnosis.

\subsection{Research Field and Method}

The total information portal service for urban regeneration was largely divided into an information analysis service for urban regeneration and an information disclosure service. In this study, a system was constructed in consideration of functions for district level decline diagnosis, as well as potential analysis for cities, counties and districts in total information portals.

The information analysis service can construct and control analytical information specified for districts. The information disclosure service has functions to allow recycling of information, connection with analysis service and participation of experts. Particularly, for indicators built into the database, indicator pools were first prepared according to analysis of internal and external similar indicators. Also, preliminary indicators were set through survey with experts. Among them, the final indicators were selected by way of expert consultation. Accordingly, this study aims to construct a total information portal service for Korean urban regeneration in consideration of extension of the existing urban decline diagnosis system for cities and counties. In particular, it aims to give a description of service construction from a viewpoint of system implementation,

\subsection{Existing Research Result}

Urban regeneration can be defined as the 'comprehensive and integrated vision and act for solving urban problems which can continuously improve the economic, physical, social, and environ-

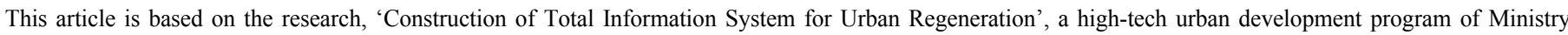
of Land, Transport and Maritime Affairs.

1) Principal Research Engineer, Land \& Housing Institute, Korea Land \& Housing Corporation (Main author: blue@lh.or.kr)

2) Research Engineer, Land \& Housing Institute, Korea Land \& Housing Corporation (Corresponding author: thelifeyyh@nate.com) 
mental status of transforming regions' according to its existing definition (Roberts, P. and H. Sykes, 2000). Furthermore, as urban regeneration refers to the improvement in economy, society, and culture in addition to the physical environment, the extent of its definition is also expanded from the improvement of deteriorated areas ('redevelopment') to overall improvement of the existing city.

In fact, there have been almost no systems for supplying information on urban regeneration, in spite of its gradually increasing importance. KOPSS (Korea planning support systems) has recently developed a system for providing information on urban regeneration, that is restricted to physical information only.

According to previous studies related to this study, the urban decline diagnosis system for cities, counties and districts was constructed (Yang and $\mathrm{Yu}, 2011$ ). With functions for decline diagnosis and indicator management. It applied OGC (Open Geospatial Consortium) standard map service technology and open API (Application Programming Interface) technology. It also applied RIA (Rich Internet Application)-based web interface technology for improvement of visual expression of analytical results and user accessibility.

Accordingly, for DB construction, with all cities, counties and districts in Korea as the objects, standard DB was constructed by actively using indicator data based on precedent studies, and then meta data were constructed.

\subsubsection{System Function and Analysis Process}

System functions are indicator management, diagnostic analysis (decline diagnosis for cities, counties and districts), main page, information disclosure and so on.

The system diagnosis function is divided into indicator analysis and diagnostic pattern analysis. In other words, the indicator analysis is a function of indicating results of the analysis of decline diagnosis according to indicators. It sets objects through processes of selecting areas for analysis (i.e., comparison among administrative districts, similar districts, and cities, counties and districts), points of time and indicators. According to the set conditions, an analytical map is displayed on the map screen and a chart dashboard is activated to refer to values according to the current states, comparative analysis (if cities, counties and districts is selected as areas for analysis) and contents on changes on the chart. The chart of changes allows interlocking with a multi-divisional map for visual comparison of the analytical map in two specific points. Under the maintenance of the previously set areas and points of time for analysis, analytical results can be immediately checked by changes in selected indicators.

The diagnostic pattern analysis is a function of making a synthetic analysis of total individual indicators or population . society, industrial economy and physical environments. The selection of objects for analysis is achieved by selecting areas for analysis, diagnostic patterns and points of time times in order.
The diagnostic pattern is selected by setting an analytical pattern from 4 patterns (i.e., total, population-society, industrial economy and physical environment) and selecting a selection indicator, except basic essential indicators. In case of the total pattern, a process of setting weight for 3 subordinary patterns is added. According to the set conditions, information displayed on the screen is provided the same as results of indicator analysis.

The total information system for urban regeneration is constructed to basically display analytical results on a map and visualize various statistical information on a chart, which is difficult to be displayed on a map. For the chart, items are set differently according to areas and patterns for analysis.

\subsubsection{Database Design and Construction}

Among the configuration items of the total DB for urban regeneration, indicator information displays indicator research results to proceed to a process for processing and constructing raw data. Basically, a process of re-estimating indicator values included in raw data into relative ranking is undergone.

A list of construction object data consists of indicator data, meta data, code list and administrative district boundary.

\subsubsection{System UI Design}

The total information system for urban regeneration aims at structural interface design to lead various classes of users to easily utilize their desired functions. In this regard, it made an analysis of similar existing cases, as well as benchmarking. Moreover, for successful UI (User Interface) design, it designed a system interface to allow a modular UI design, a preferred user UI configuration, and data transaction and expression at a UI level. In the total information system for urban regeneration, main interface components, as shown in Fig. 1, are a toolbar on the top of the screen, a chart dashboard showing results, a wizard form for executing input of conditions by stages, and a button bar

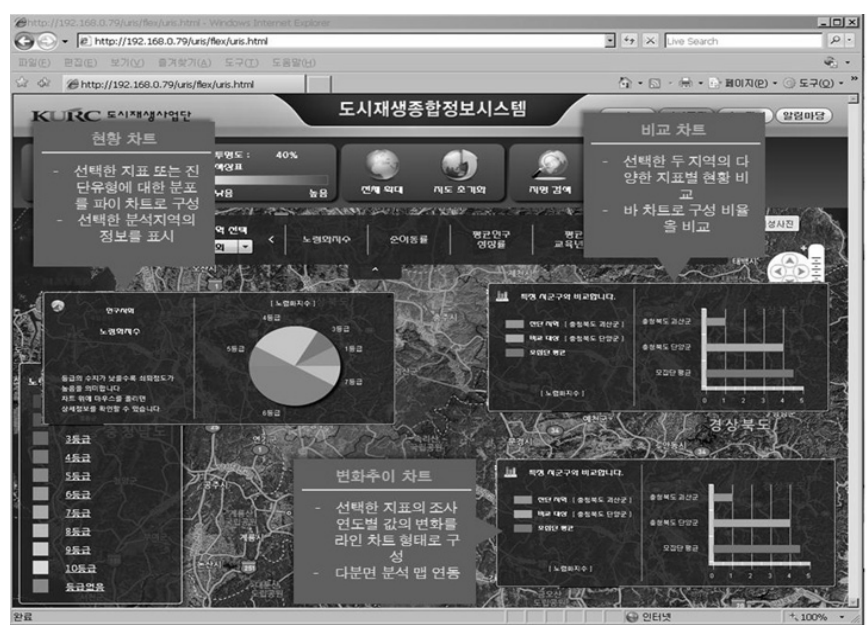

Fig. 1. City and district level decline diagnosis system UI configuration 
form with improved accessibility for quickly executing a command.

\section{Information Analysis Service For Urban Regeneration}

\subsection{Construction Background}

Based on improvement plans of total information systems for urban regeneration according to previous studies, diverse application plans for information systems were required, in addition to systematic support for the urban regeneration business, to be improved, according to the application of technologies for utilizing spatial information, as well as the trend of urban regeneration, to efficiently supply information services. In this study, therefore, the information analysis service, including the district level decline diagnosis and potential analysis, was implemented, as well as the information disclosure service for smooth establishment of common utilization systems.

\subsection{Overview}

For an efficient district level1) decline diagnosis, in connection with Korea's city and the district level decline diagnosis system that was developed in existing studies, this service established a spatial phase structure in the unit of administrative dong and output area ${ }^{2}$ ) in the relevant city and district. In order to enhance the efficiency of spatial analysis, it also allowed random and multiple selection of real users on their areas of interest (eup, myeon, dong, output area, etc.). Moreover, it was built to connect an extracted area of interest with setting of conditions for multiple indicators. According to the connection of functions of the information analysis service for urban regeneration with Road View API on the common map, it led to the approximate monitoring of the physical status in areas of interest prior to actual field investigation to facilitate improved work efficiency. It also rated information for analysis by way of reprocessing raw data. In view of connection with the information disclosure service, it managed analysis activities according to the division of users.

The main features of the system architecture are shown in Fig. 2 . In other words, construction of platforms with applied spatial information service standards, implementation of RIA application for effective analytical expressions and construction of whole open source-based SW frameworks are shown.

In the database area, district level decline diagnosis DB and potential analysis indicator DB were constructed. A DBMS

1) The district unit refers to a spatial size smaller than the city/county/district unit of the country, and indicates eup/myeon/ dong unit and output area included in the unit.

2) As the enumeration unit for the National Statistical Office, two or three basic enumeration districts are collected to set an output area, which consists of a minimum population of 10,000 people. (Eup/myeon/dong can consist of about 30 output areas).

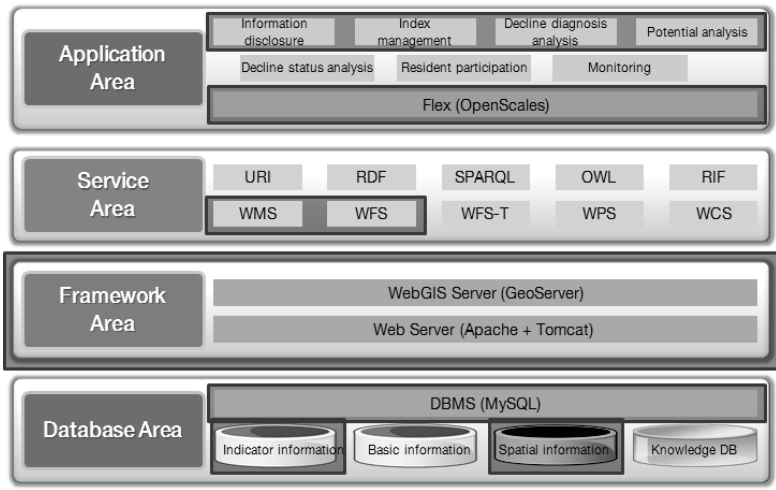

Fig. 2. System architecture configuration

Table 1. Diagnostic patterns by modules

\begin{tabular}{c|c|c|c}
\hline Division & $\begin{array}{c}\text { City and District } \\
\text { Level Decline } \\
\text { Diagnosis }\end{array}$ & $\begin{array}{c}\text { District Level Decline } \\
\text { Diagnosis }\end{array}$ & $\begin{array}{c}\text { Potential } \\
\text { Analysis }\end{array}$ \\
\hline \multirow{2}{*}{$\begin{array}{c}\text { Diagnostic } \\
\text { pattern }\end{array}$} & $\begin{array}{c}\text { Population·Society } \\
\text { Industrial economy } \\
\text { Physical } \\
\text { environment }\end{array}$ & $\begin{array}{c}\text { Population-Society } \\
\text { Industrial economy } \\
\text { Physical environment }\end{array}$ & $\begin{array}{c}\text { Human } \\
\text { resource base } \\
\text { Economic base } \\
\text { Living base } \\
\text { Social and } \\
\text { cultural base }\end{array}$ \\
\hline
\end{tabular}

(DataBase Management System) used MySQL in consideration of generality and extensibility based on the existing oracle. In the framework area, a web-based spatial information platform was constructed to implement a standard web map service. As for the WebGIS server, GeoSever was used. Moreover, Apache and Tomcat was used as the WebSever.

Service functions are largely divided into decline diagnosis and potential analysis. Decline diagnosis includes city/county/ district level and district level. In particular, the district level is classified into eup/myeon/dong level and output area level.

\subsection{Information Analysis Process}

In addition to common functions of referring to individual indicators, this information analysis process consists of analysis processes according to diagnostic patterns to lead users to select an indicator and give weight to produce outputs, in case of city/county/district level/district level decline diagnosis and potential analysis.

In the diagnostic pattern analysis process, after selection of a diagnostic pattern, its analytical indicator is selected. When rating is performed according to essential indicators and user-selected indicators, diagnosis map/chart is displayed on map (Fig. 3).

For district level decline diagnosis, a process for extracting areas of interest was implemented to extract only areas that correspond to ranges suitable for their conditions, after selection of multiple indicators, as shown in Fig. 4. This process allows the 


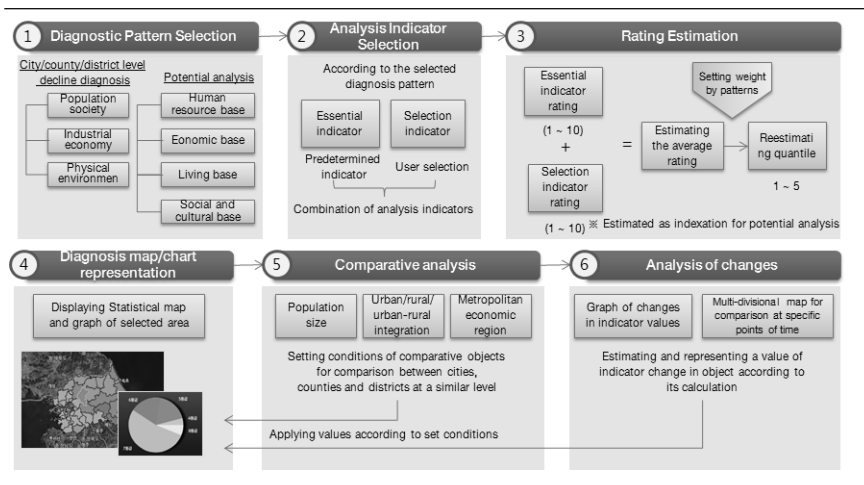

Fig. 3. Diagnostic pattern analysis process

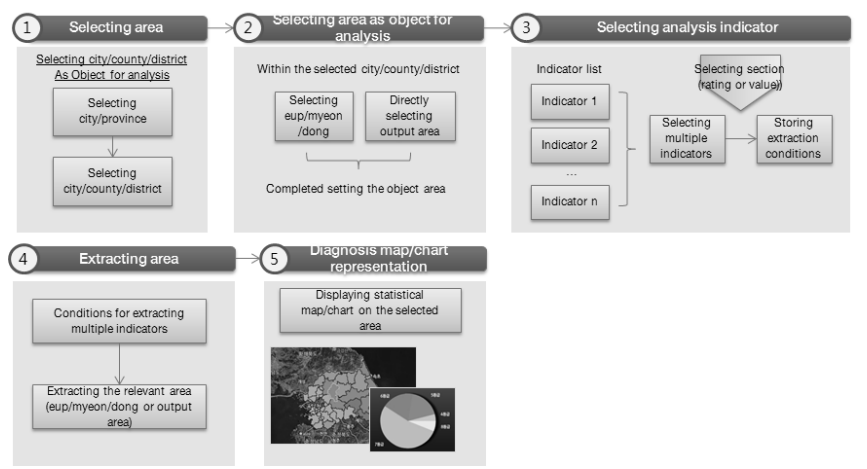

Fig. 4. Process for extracting areas of interest

relevant area to be displayed on the diagnosis map/chart, when an area is selected at an eup/myeon/dong level or output area level and its analytical indicator.

\subsection{Service Functional Configuration}

The entire screen configuration for service consists of service menus on the top, dashboard panels for setting analysis and monitoring results on the left, and individual indicator selection areas and map control areas above the map (Fig. 5).

According to the basic screen configuration, as shown in Fig. 5 , (1) indicates main menus consisting of decline diagnosis, potential analysis, indicator management and notice board. (2) indicates submenus, detailed settings and output window. (3) shows an indicator setting area and (4) shows a map control area. In the area, sever 1 functions are implemented, for example, moving administrative districts, controlling transparency of statistical layers, storing images, controlling thematic map layer on/off, road view on/off, Naver map general/satellite on/off, zoom bar, extension, map initialization and so on.

Fig. 6 depicts a screen showing the performance of city and district level decline diagnosis according to indicators. It consists of analysis settings above the dashboard panel area on the left, chart representation in the middle and information display at the bottom. For potential analysis, same functions are implemented, and results of city and district level potential analysis can be monitored, when (8) View potential results is selected.

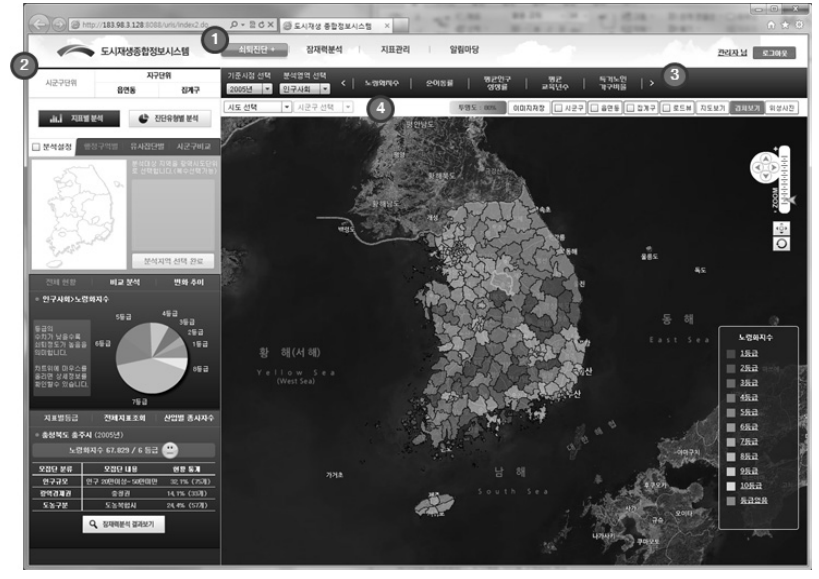

Fig 5. Basic screen configuration

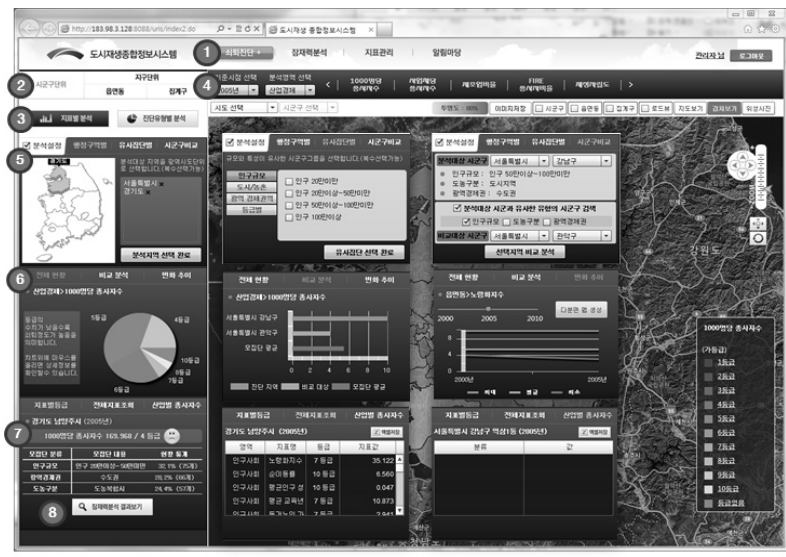

Fig. 6. Decline diagnosis - city and district level indicator analysis

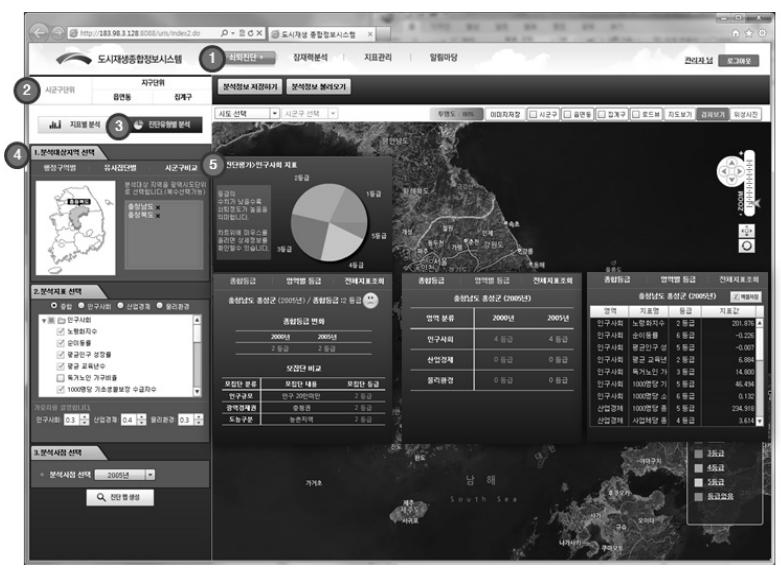

Fig. 7. Decline diagnosis - city and district level diagnostic pattern analysis

As shown in Fig. 7, diagnostic pattern analysis screen is designed to set conditions by steps on the dashboard. (selection of areas for analysis- $>$ selection of analysis indicators- $>$ selection of points of time for analysis) The results of the analysis are displayed on the chart and information inquiry screen. 


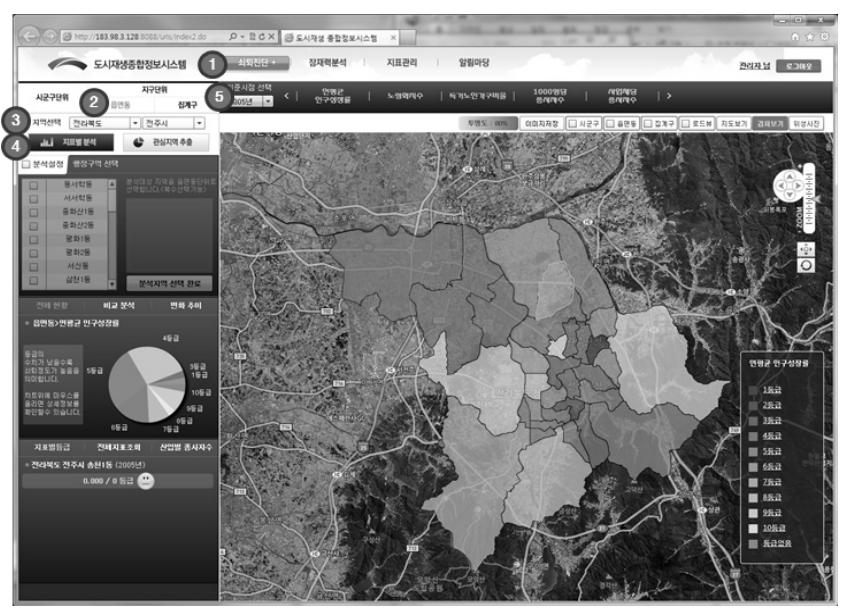

Fig. 8. Decline diagnosis - district level(eup/myeon/dong) indicator analysis

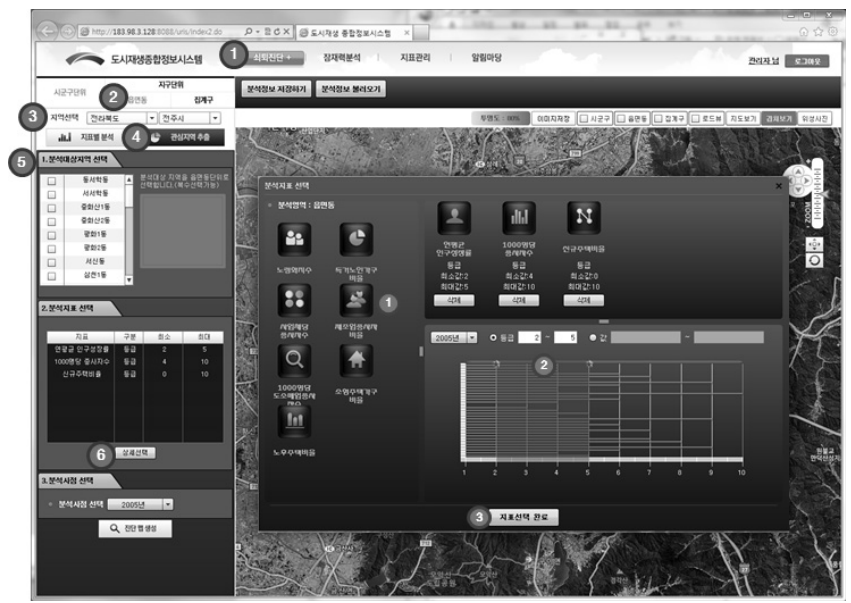

Fig. 9. Decline diagnosis - district level (eup/myeon/dong) area of interest extraction

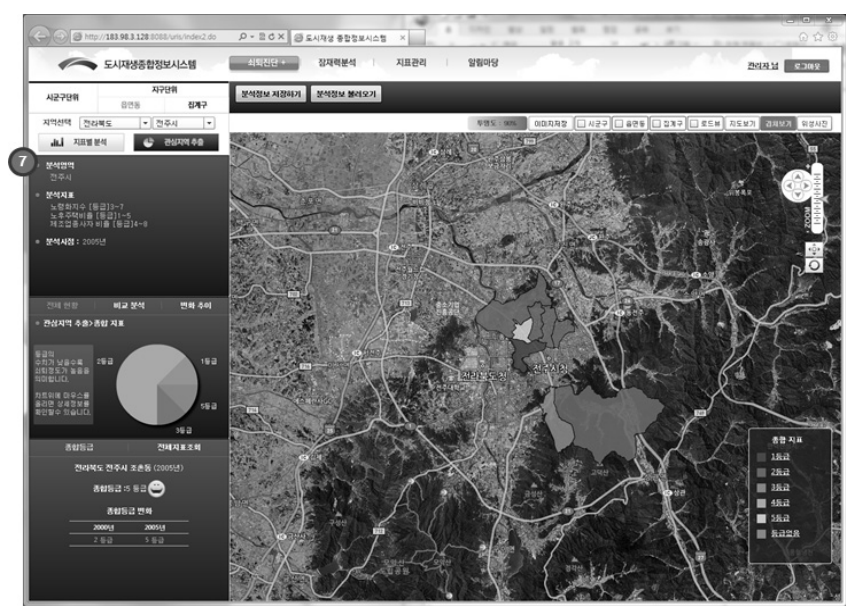

Fig. 10. Results of areas of interest extraction

As shown in Fig. 8, the district level decline diagnosis function can analyze spatial units, which are subdivided into eup/myeon/ dong and output areas. The indicator analysis has an architecture similar to that of city and district levels. Moreover, the eup/myeon/ dong level indicator analysis has the same execution process and result pattern as the city and district level analysis.

In the district level decline diagnosis, the function of extracting areas of interest, as shown in Figs. 9 and 10, selects multiple indicators by dragging them on the analysis indicator selection window and sets selection sections corresponding to the indicators to extract areas suitable for the conditions.

\subsection{Construction of Urban Regeneration Integrated DB}

In this study, decline diagnosis indicators, potential indicators DB and operational spatial information were constructed. Among them, the city and district level decline diagnosis DB was already constructed in precedent studies.

District level indicators were based on output area level statistical data from SGIS of National Statistical Office. However, some indicators were constructed by using data on the rates of adjacent areas from LH SDW3), and the serial cadastral map and the use district map from KLIS. For data construction, potential analysis indicators are shown to have various sources and numerous items which require individual input. In this regard, for maintenance and management, a survey input process is required.

\subsection{Establishment of Plans for Construction of Spatial Information for Urban Regeneration}

In this study, the current status on the construction of data based on spatial information models for urban regeneration, in addition to development plans, was established to construct efficient spatial information. Unlike a central user model, a local user model requires a process of analyzing information on the current status through spatial analysis. Accordingly, data to be quantitatively extended and spatially diversified should be constructed. Moreover, in order to satisfy the demand on 3D information, the collaborative utilization of open platforms of Ministry of Land, Transport and Maritime Affairs and their utilization should be considered.

Instead of construction by collected physical data, spatial reference information is constructed to reduce the maintenance burden in connection with the standard map-based service and secure the freshness of information.

The 3D 'open platform' service, supplied by Ministry of Land, Transport \& Maritime Affairs which takes the lead in Korea's spatial information policies, supplies almost all the spatial information that is disclosed according to the recent IT trend. It is now under pilot operation and will continuously facilitate extended operation. It is also judged to implement collaborative applications in the information analysis service for urban regeneration by support of map service API and data API.

3) LH SDW (Spatial Data Warehouse) 
Table 2. Status on construction of (output area level) decline diagnosis indicator DB

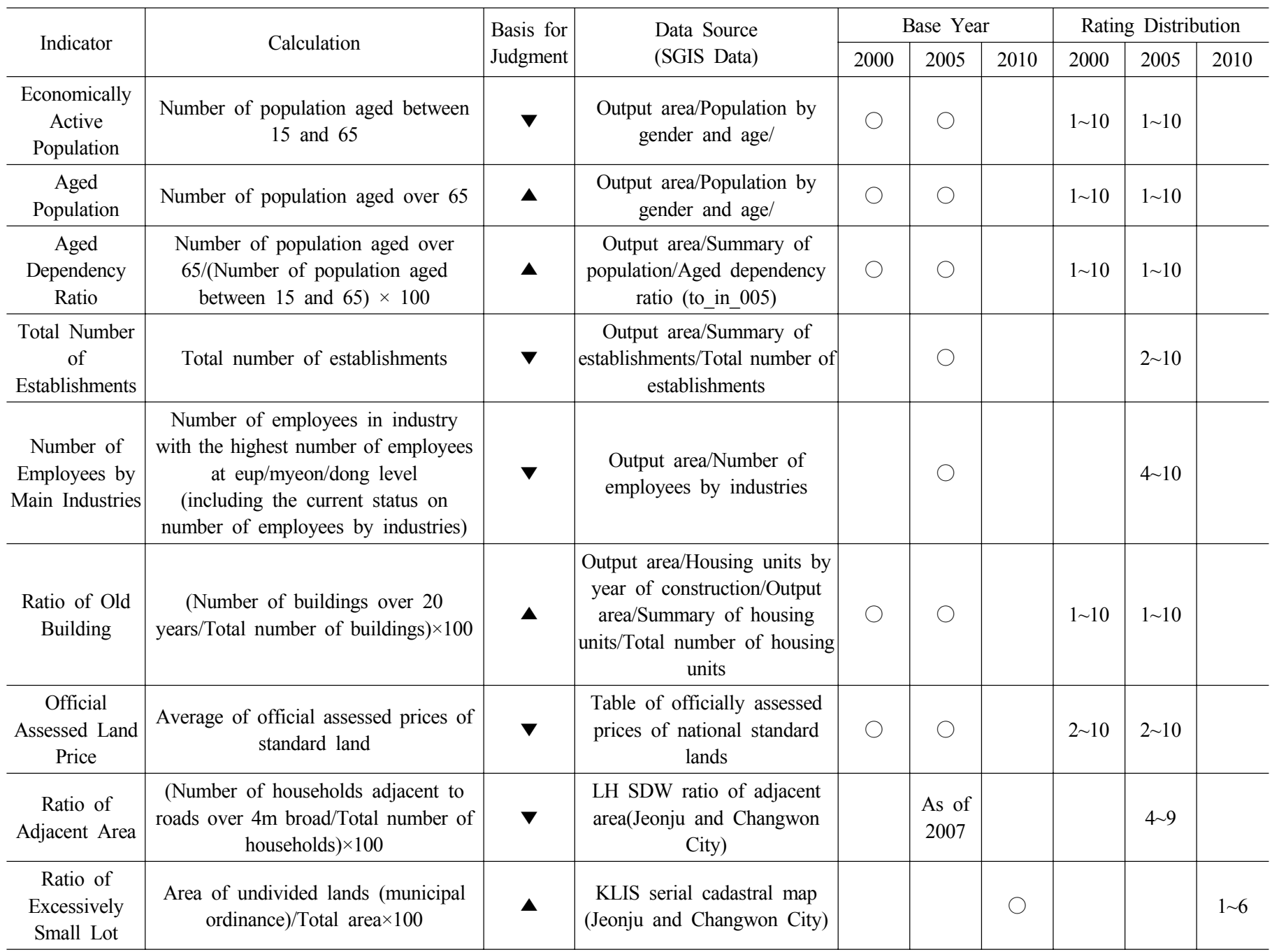

If local governments require local diagnosis and analysis of the current status on regeneration conditions, the role of spatial information will be considerably extend. Accordingly, it is necessary to consider plans for effective collaborative utilization of information of other organizations, which supply related data and services. Particularly, KOPSS with spatial information analysis module-based service seems to be a highly available system. In this regard, the feasibility of connection on this system and methods were analyzed. For KOPSS, the C/S-based system is now under pilot operation in model local governments (Daegu and Jeju). For its collaborative utilization, OpenAPI service should be implemented, but it has not yet been done. Instead, it will be applied later to additional local governments. As a result, for now, there is no object for collaborative utilization of KOPSS analysis module, which requires continuous monitoring.

For further KOPSS OpenAPI connection, technical plans were considered. The connection method is to implement KOPSS API, a model service that is a set of unit functions specified in domain areas, in client applications of the urban regeneration system. In other words, according to API, unit functions (WPS, WFS, etc.) of KOPSS are operated, and results are received in GML document format and rendered (Fig. 12). If utilization of connection on analysis modules is achieved through KOPSS, it is judged that it will allow connection on LH SDW data provided with various spatial information and $3 \mathrm{D}$ information of the open platform connection. Both of the systems are constructed to support OpenAPI for service-based connection. The connection with other systems has been technically reviewed. However, the current central user model is a diagnostic process based on indicator information, which has low availability in spatial elements. For practical use, it is judged to be utilized for analysis of information on the current status in local user models.

\section{Urban Regeneration Information Disclosure Service}

This information disclosure service refers to a portal service, which targets the supplying recyclable information, promoting communities with a participation function and sharing results of 
Table 3. Status on construction of (city and district level) potential indicator DB

\begin{tabular}{|c|c|c|c|c|c|c|c|c|c|c|}
\hline \multirow{2}{*}{ Domain } & \multirow{2}{*}{ Indicator } & \multirow{2}{*}{ Calculation } & \multirow{2}{*}{$\begin{array}{l}\text { Basis for } \\
\text { judgment }\end{array}$} & \multirow{2}{*}{ Data Source(Review) } & \multicolumn{3}{|c|}{ Base Year } & \multicolumn{3}{|c|}{ Rating Distribution } \\
\hline & & & & & 2000 & 2005 & 2010 & 2000 & 2005 & 2010 \\
\hline \multirow{4}{*}{$\begin{array}{l}\text { Human } \\
\text { Resource } \\
\text { Base }\end{array}$} & $\begin{array}{c}\text { Ratio of population of college and } \\
\text { university graduates }\end{array}$ & $\begin{array}{c}\text { Number of university graduates } \\
\text { and over/Total number of } \\
\text { population }\end{array}$ & $\Delta$ & $\begin{array}{l}\text { National Statistical Office } \\
\text { (KOSIS population census) }\end{array}$ & $\mathrm{O}$ & $\mathrm{O}$ & $\mathrm{O}$ & $1 \sim 8$ & $1 \sim 8$ & $1 \sim 8$ \\
\hline & Ratio of female employees & $\begin{array}{c}\text { Number of female } \\
\text { employees/Total number of } \\
\text { employees }\end{array}$ & $\Delta$ & $\begin{array}{c}\text { National Statistical Office(KOSIS } \\
\text { labor section /Status on labor } \\
\text { force at establishments) }\end{array}$ & $\mathrm{O}$ & $\mathrm{O}$ & & $1 \sim 10$ & $1 \sim 10$ & \\
\hline & $\begin{array}{c}\text { Growth rate of population aged } \\
\text { under } 20\end{array}$ & $\begin{array}{c}\text { (Population aged under } 20 \text { for } \\
\text { target year - population aged } \\
\text { under } 20 \text { for base } \\
\text { year)/population aged under } 20 \\
\text { for base year x } 100\end{array}$ & $\Delta$ & $\begin{array}{l}\text { National Statistical Office } \\
\text { (KOSIS population census) }\end{array}$ & $\mathrm{O}$ & $\mathrm{O}$ & $\mathrm{O}$ & $1 \sim 10$ & $1 \sim 8$ & $1 \sim 9$ \\
\hline & $\begin{array}{c}\text { Voting rate } \\
\text { (Heads of local governments, } \\
\text { members of the National } \\
\text { Assembly and President) }\end{array}$ & $\begin{array}{c}\text { Average voting rate for recent } 5 \\
\text { years (Heads of local } \\
\text { governments/Members of the } \\
\text { National Assembly/President) }\end{array}$ & $\Delta$ & $\begin{array}{c}\text { National Election Commission } \\
\text { /Election information library } \\
\text { (Historic election information } \\
\text { system) }\end{array}$ & $\mathrm{O}$ & $\mathrm{O}$ & $\mathrm{O}$ & $2 \sim 9$ & $1 \sim 9$ & $1 \sim 9$ \\
\hline \multirow{5}{*}{$\begin{array}{l}\text { Economic } \\
\text { Base }\end{array}$} & GRDP per capita & GRDP/total number of population & $\Delta$ & \begin{tabular}{|} 
National Statistical Office(KOSIS \\
statistics by institutions) \\
/municipal(provincial) homepages
\end{tabular} & $\mathrm{O}$ & $\mathrm{O}$ & & & & \\
\hline & Financial independency & - & $\Delta$ & $\begin{array}{c}\text { National Statistical Office(KOSIS } \\
\text { online publications), Local } \\
\text { Finance Open System, Ministry } \\
\text { of Strategy and Finance }\end{array}$ & $\begin{array}{c}\mathrm{O} \\
(2001)\end{array}$ & $\mathrm{O}$ & $\mathrm{O}$ & $1 \sim 9$ & $1 \sim 8$ & $1 \sim 8$ \\
\hline & Number of patent applications & $\begin{array}{c}\text { Number of regional patent } \\
\text { applications }\end{array}$ & $\Delta$ & $\begin{array}{c}\text { Korean Intellectual Property } \\
\text { Office (Annual statistics report on } \\
\text { intellectual property } \\
\text { /trend of Korean intellectual } \\
\text { property rights) }\end{array}$ & & $\begin{array}{c}\mathrm{O} \\
(2006)\end{array}$ & $\mathrm{O}$ & & $1 \sim 6$ & $1 \sim 6$ \\
\hline & Residence tax per capita & $\begin{array}{c}\text { Total residence taxes/total number } \\
\text { of population }\end{array}$ & $\Delta$ & \begin{tabular}{|c|} 
Ministry of Public Administration \\
and Security (Annual local tax \\
statistics report), Annual statistics \\
report by cities and provinces \\
\end{tabular} & $\mathrm{O}$ & $\mathrm{O}$ & & $1 \sim 6$ & $1 \sim 6$ & \\
\hline & $\begin{array}{l}\text { Number of employees to } \\
\text { economically active population }\end{array}$ & $\begin{array}{c}\text { Total number of employees } \\
\text { Number of population aged } \\
\text { between } 15 \text { and } 65\end{array}$ & $\Delta$ & \begin{tabular}{|c|} 
National Statistical \\
Office(institutions/employment \\
and labor)
\end{tabular} & $\mathrm{O}$ & $\mathrm{O}$ & & $1 \sim 7$ & $1 \sim 7$ & \\
\hline \multirow{5}{*}{$\begin{array}{l}\text { Living } \\
\text { Base }\end{array}$} & Park area per capita & $\begin{array}{l}\text { Total area of urban parks/Total } \\
\text { number of population(population } \\
\text { in terms of registered residents) }\end{array}$ & $\Delta$ & $\begin{array}{c}\text { National Statistical Office(KOSIS } \\
\text { statistics by institutions/Basic } \\
\text { statistics by local governments), } \\
\text { Annual statistics report by cities, } \\
\text { counties and districts } \\
\end{array}$ & $\mathrm{O}$ & $\mathrm{O}$ & & $1 \sim 6$ & $1 \sim 7$ & \\
\hline & Road density & Road area/total area & $\Delta$ & $\begin{array}{c}\text { Annual statistics report by cities } \\
\text { and provinces }\end{array}$ & $\mathrm{O}$ & $\mathrm{O}$ & & $1 \sim 7$ & $1 \sim 7$ & \\
\hline & Population per civil servant & $\begin{array}{c}\text { Total number of } \\
\text { population/Number of civil } \\
\text { servants }\end{array}$ & $\Delta$ & $\begin{array}{c}\text { Annual statistics report by cities } \\
\text { and provinces }\end{array}$ & $\mathrm{O}$ & $\mathrm{O}$ & & $1 \sim 8$ & $1 \sim 8$ & \\
\hline & $\begin{array}{c}\text { Growth rate of permitted areas for } \\
\text { building construction from the } \\
\text { previous year }\end{array}$ & $\begin{array}{c}\text { (Permitted areas for building } \\
\text { construction for target year - } \\
\text { Permitted areas for base year) } \\
\text { /Permitted areas for base year } \mathrm{x} \\
100\end{array}$ & $\Delta$ & $\begin{array}{c}\text { National Statistical Office(KOSIS } \\
\text { Administration section/Public } \\
\text { administration/Korea Municipal } \\
\text { Yearbook), Basic statistics, } \\
\text { Annual statistics report by cities } \\
\text { and provinces, Annual statistics } \\
\text { report by cities, counties and } \\
\text { districts }\end{array}$ & $\mathrm{O}$ & $\mathrm{O}$ & & & $1 \sim 7$ & \\
\hline & $\begin{array}{l}\text { In/out migration rate of registered } \\
\text { residents }\end{array}$ & $\begin{array}{c}\text { (In-migrant } \\
\begin{array}{c}\text { population-Out-migrant } \\
\text { population)/Total population }\end{array} \\
\end{array}$ & $\Delta$ & $\begin{array}{c}\begin{array}{c}\text { National Statistical Office(KOSIS } \\
\text { population movement) }\end{array} \\
\end{array}$ & $\mathrm{O}$ & $\mathrm{O}$ & $\mathrm{O}$ & $1 \sim 10$ & $1 \sim 10$ & $1 \sim 10$ \\
\hline \multirow{5}{*}{$\begin{array}{c}\text { Social and } \\
\text { Cultural } \\
\text { Base }\end{array}$} & Recycling rate of wastes & $\begin{array}{c}\text { (Volume of waste recycling/Total } \\
\text { amount of wastes) } \times 100\end{array}$ & $\Delta$ & $\begin{array}{c}\text { Annual statistics report by cities } \\
\text { and provinces }\end{array}$ & $\mathrm{O}$ & $\mathrm{O}$ & & $2 \sim 10$ & $1 \sim 10$ & \\
\hline & $\begin{array}{l}\text { Number of welfare facilities per } \\
10,000 \text { persons }\end{array}$ & $\begin{array}{c}\text { Number of social welfare } \\
\text { facilities } / 10,000\end{array}$ & $\Delta$ & \begin{tabular}{|c|} 
National Statistical Office(KOSIS \\
statistics by institutions/Basic \\
statistics by local governments)
\end{tabular} & $\mathrm{O}$ & $\mathrm{O}$ & & $1 \sim 8$ & $1 \sim 8$ & \\
\hline & $\begin{array}{l}\text { Number of cultural/sports } \\
\text { facilities per } 10,000 \text { persons }\end{array}$ & $\begin{array}{c}\text { (Number of cultural } \\
\text { facilities+Number of sports } \\
\text { facilities) } / 10,000\end{array}$ & $\Delta$ & $\begin{array}{c}\text { National Statistical Office(KOSIS } \\
\text { statistics by institutions/Basic } \\
\text { statistics by local governments) }\end{array}$ & $\mathrm{O}$ & $\mathrm{O}$ & & $1 \sim 8$ & $1 \sim 8$ & \\
\hline & $\begin{array}{c}\text { Number of festivals per } 10,000 \\
\text { persons }\end{array}$ & Number of festivals/10,000 & $\Delta$ & $\begin{array}{c}\text { Statistical portal service for } \\
\text { culture, sports and tourism(status } \\
\text { on local festivals) }\end{array}$ & $\mathrm{O}$ & $\mathrm{O}$ & $\mathrm{O}$ & $1 \sim 7$ & $1 \sim 8$ & $1 \sim 8$ \\
\hline & $\begin{array}{c}\text { Number of nonprofit } \\
\text { organizations }\end{array}$ & - & $\boldsymbol{\Delta}$ & $\begin{array}{c}\text { Local Administration Bureau, } \\
\text { Ministry of Public } \\
\text { Administration Security } \\
\end{array}$ & & $\mathrm{O}$ & $\mathrm{O}$ & & $1 \sim 7$ & $1 \sim 7$ \\
\hline
\end{tabular}


Table 4. Current status on construction of (eup/myeon/dong level) decline diagnosis indicator DB

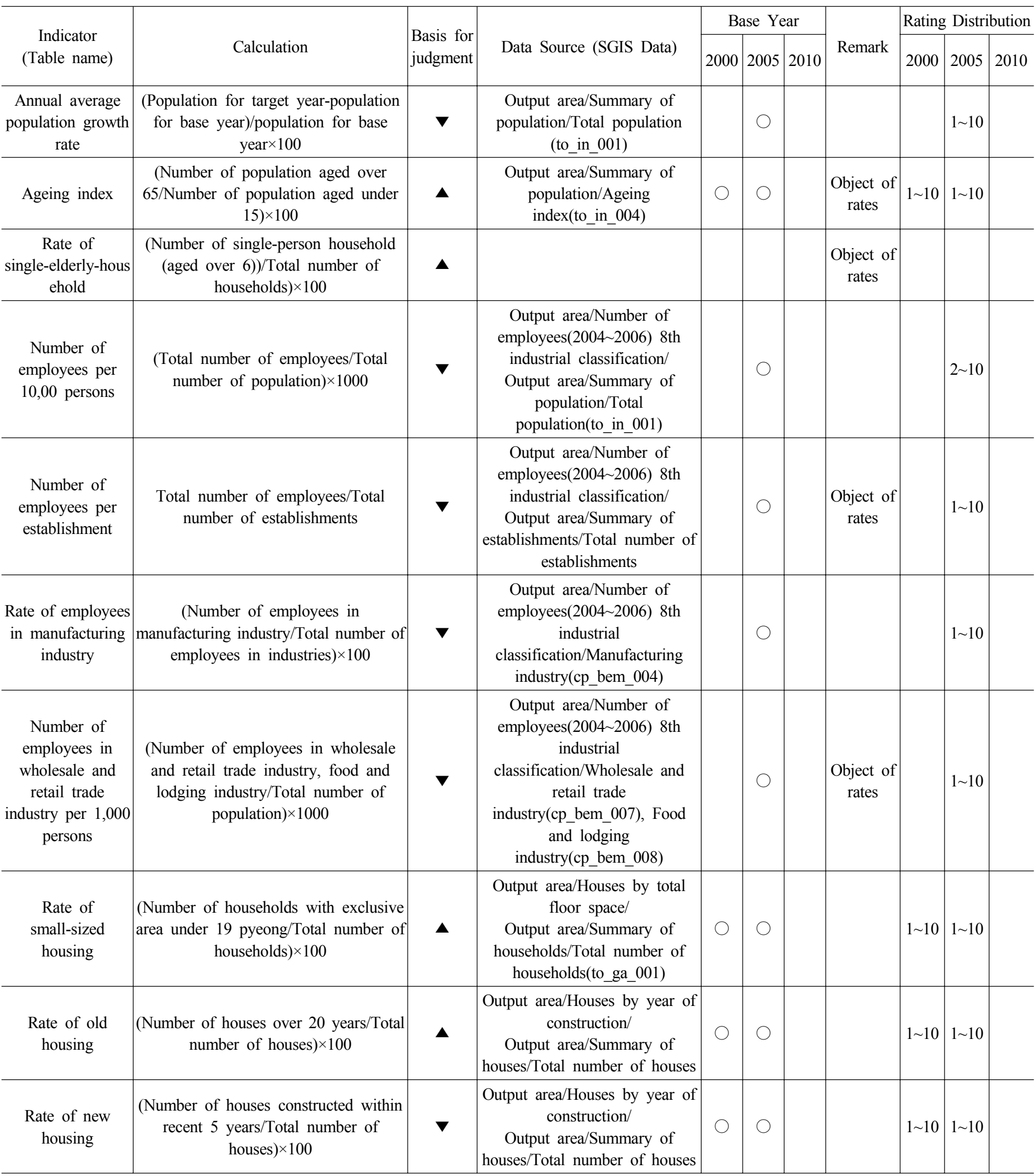

information analysis service. In order to design the information disclosure service, the demand on functions was derived from various classes of users. Then, key words were made on opinion sharing, information acquiring, analysis tools and information subscription, for policy-making institutions, project management institutions and research institutions to function as both an information supplier and demander and to facilitate communities. In view of the demand (Fig. 13), the basic functional framework 


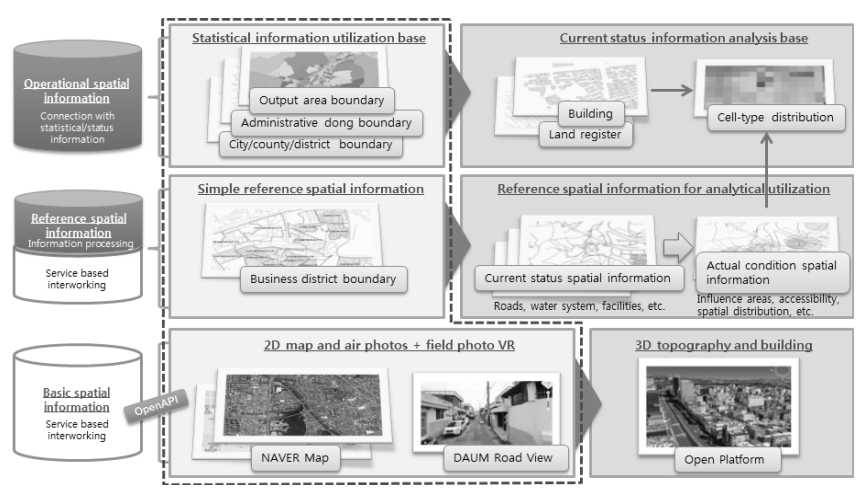

Fig. 11. Spatial information model

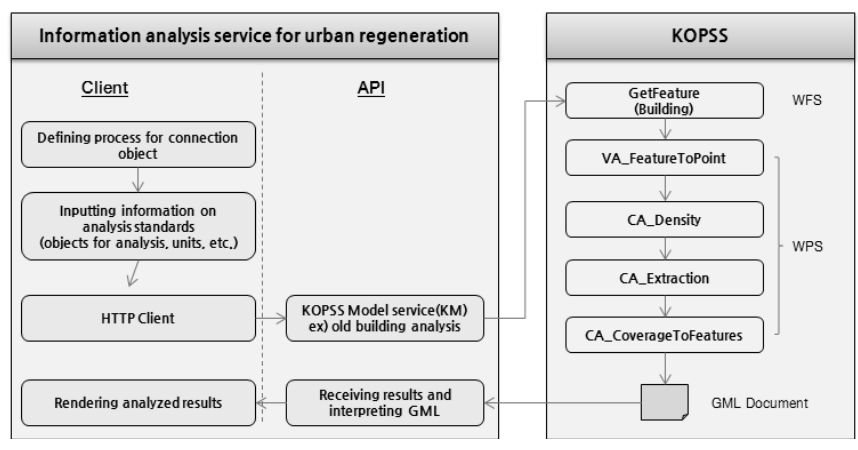

Fig. 12. KOPSS relationship diagram

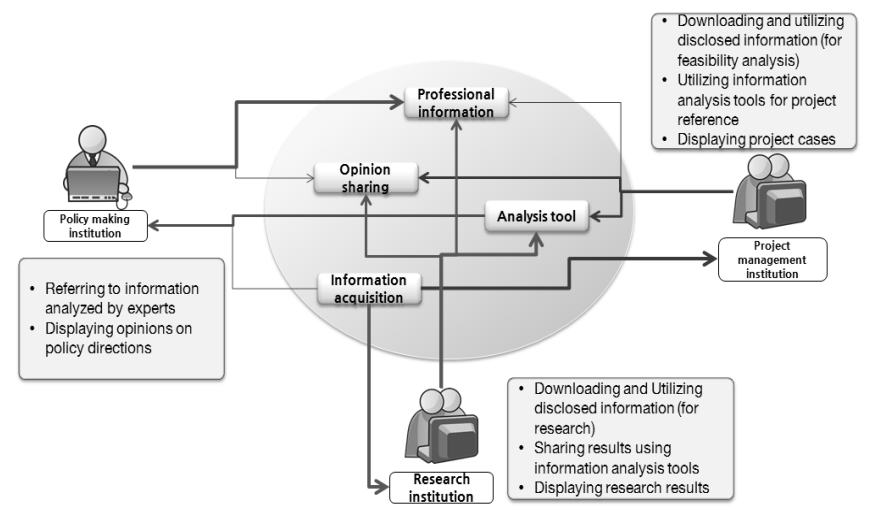

Fig. 13. Service function and information demand analysis

of the information disclosure service was designed as follows. The service is largely divided into sections of information retrieval and downloadable information disclosure, information analysis for interworking with the analysis service and for sharing results, and forums and blogs for opinion sharing and professional information subscription.

In other words, it has the framework of supplying results of the analysis service through the information disclosure service and displaying the stored results which are called from the analysis service, when referring to results of analysis activities through the information disclosure service. For this, information on analysis activities (profiles) is separately managed. Fig. 14 is a conceptual diagram illustrating interconnection between the information

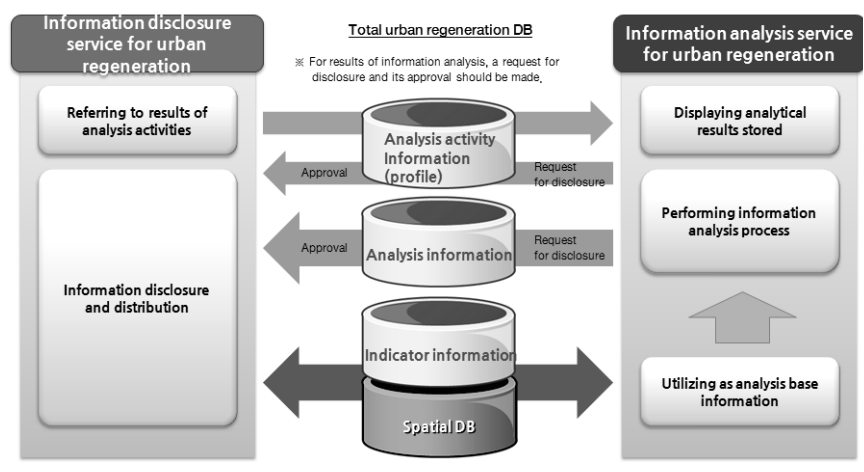

Fig. 14. Information analysis and service interworking conceptual diagram

disclosure and the information analysis service.

The information disclosure section is provided with an interactive screen for users to easily approach and utilize information. The information analysis section consists of an area for executing information analysis service and an area for sharing results on analysis activities. Moreover, it includes a forum and blog section for community revitalization.

\section{Conclusions and Future Research}

In this study, the total information portal service for urban regeneration was constructed to supply information analysis services such as city and district level decline diagnosis and potential diagnosis. For decline and potential analysis, DB was constructed. It utilized data from National Statistical Office for easier acquisition and renewal.

Likewise, this portal service aims to supply various information to establish comprehensive plans for urban regeneration, which are suitable for local conditions, in consideration of local features and differences. It will also supply various contents to spontaneously form and manage sustainable development conditions to supply various contents of communities for urban regeneration. According to this study, utilization of the total information portal service for urban regeneration is expected to ease monitoring of fundamental problems which cause urban decline and preferred demands for urban regeneration. To achieve this, a survey and evaluation of various matters (physics, society, economy, culture) across the entire city must precede, and the effects of prior planning activities for achieving specification in reality will be maximized through such use.

For a more efficient information analysis service, future research will lead users, that is, central users, local governments, general users, etc., to easily approach their desired information by implementation of user management functions. Moreover, it will complement indicator management functions. In the information disclosure service section, detailed functions of web services will be implemented and interworked with the information analysis service. After correction and complementation through service 
tests, pilot operation will be performed to derive complementary items.

On the basis of the derived results, the information analysis system for urban regeneration will be constructed, and a preferred site selection system will be developed. Then, a participatory information communication system will be prepared by implementation of residents' participation services. In the DB construction section, all spatial information for urban regeneration will be constructed and locally specialized information will be supplied through the construction of locally specialized DB.

In this study, the total information portal service for urban regeneration can provide various information to allow the establishment of total urban regeneration plans to be suitable for regional circumstances, in consideration of regional characteristics and differences, such as causes and actual conditions of decline. Moreover, this information consists of information on urban regeneration related projects by central ministries and offices, project regulations and support, urban regeneration law-based support and incentives, and various urban regeneration support systems and programs, which serve to establish total urban regeneration plans suitable for regional circumstances. The application of the total information portal service for urban regeneration is also expected to facilitate solving fundamental problems that facilitate urban decline and allow easier monitoring of preferred demands for urban regeneration.

\section{References}

1. Chen, Y. and S. Knapp (2006), VEPS-Virtual Environmental Planning System: First steps towards a web-based 3D-planning and participation tool.

2. Ellul, C. (2008), Creating Community Maps for the London Tames Gateway.

3. GOLUBOVIC-MATIC (2006), Geographic Information Systems on the Internet: Sustainable Solution for the Information Society.

4. Korea Land \& Housing Corporation (2010), Spatial Data Warehouse Step 1 Completion Report on 'Information Strategic Planning'.

5. Ministry of Land, Transport \& Maritime Affairs (2010), Digital Land Expo, NSDI KOREA

6. National Information Society Agency (2010), Evolution of Web Technology and Application Direction of Public Service.

7. Roberts, P. (2000), 'Evolution, Definition and Purpose' In Roberts, P. and H. Sykes (eds) Urban Regeneration : A Handbook, Sage Publication.

8. Urban Regeneration Project Team (2009), Development of DB for Urban Regeneration and Information System Models.

9. Yang, D.-S, Y.-H. Yu (2011), "Construction of Total Information System for Urban Regeneration -Focusing on Implementation of City and District Level Decline Diagnosis System-", LHI Journal, 2(3).

10. Yang, D.-S., D.-G. Lee, S.-S. Lee (2012), "Urban potential diagnostic indicators DB construction for Urban Regeneration Information System", The 37th Conference of the KIPS, 19(1). 